\title{
Effect of essential oils of medicinal plants on leaf blotch in Tanzania grass $^{1}$
}

\author{
Efeito de óleos essenciais de plantas medicinais sobre a helmintosporiose do capim \\ Tanzânia
}

\author{
Gil Rodrigues dos Santos²*, Rúbia Borges Cruz Sarmento Brum ${ }^{3}$, Henrique Guilhon de Castro ${ }^{4}$, Clebson Gomes \\ Gonçalves $^{5}$ e Rodrigo Ribeiro Fidelis ${ }^{4}$
}

\begin{abstract}
Leaf spots caused by phyto-pathogenic fungi, can reduce the production of forage plants. The essential oils of medicinal plants have antimicrobial potential. The objective here was to evaluate the fungotoxicity in vitro of the essential oils of lemongrass (Cymbopogon citratus (DC.) Stapf (Poaceae)), citronella (Cymbopogon nardus (L.) Rendle (Poaceae)), lemon balm (Lippia alba (Mill.) $\mathrm{NE} \mathrm{Br}$ ex Britton \& P. Wilson (Verbenaceae)) and peppermint (Mentha piperita L. (Lamiaceae)) on the fungus Helminthosporium sp. and the in vivo effect of these oils and of commercial neem oil (Azadirachta indica A. Juss. (Meliaceae)) on leaf blotch in Panicum maximum Jacq. cv. Tanzania-1. The mycelial growth of the fungus was evaluated over five periods $(2 ; 4 ; 6 ; 8$ and 10 days from incubation $)$ and with five concentrations of essential oils $\left(C_{1}=250 \mathrm{ppm} ; \mathrm{C}_{2}=500 \mathrm{ppm} ; \mathrm{C}_{3}=750 \mathrm{ppm} ; \mathrm{C}_{4}=1,000 \mathrm{ppm}\right.$ e $\mathrm{C}_{5}=1,250 \mathrm{ppm}$ ). As an alternative control, the preventative and curative effect on leaf blotch of five oil-based treatments were evaluated: lemongrass, citronella, lemon balm, peppermint and neem in four concentrations $(2,500 ; 5,000 ; 7,500$ and 10,000 ppm). The essential oils of lemongrass and citronella were the most effective in reducing mycelial growth of Helminthosporium sp. With the essential oil of lemongrass, the pathogen presented the highest growth concentration (1.250 ppm). The results obtained showed that all the essential oils and concentrations tested presented a preventive and curative effect, reducing the severity of leaf blotch.
\end{abstract}

Key words: Forage plants. Essential oils. Helminthosporium sp..

RESUMO - Manchas foliares, causadas por fungos fitopatogênicos, podem reduzir a produção de forrageiras. Óleos essenciais de plantas medicinais apresentam potencial antimicrobiano. Objetivou-se avaliar a fungitoxicidade in vitro dos óleos essenciais de capim-limão (Cymbopogon citratus (DC.) Stapf (Poaceae)), citronela (Cymbopogon nardus (L.) Rendle (Poaceae)), erva-cidreira (Lippia alba (Mill.) N.E. Br. ex Britton \& P. Wilson (Verbenaceae)) e hortelã-pimenta (Mentha piperita L. (Lamiaceae)) sobre o fungo Helminthosporium sp. e o efeito in vivo desses óleos e do óleo comercial de nim (Azadirachta indica A. Juss. (Meliaceae)) sobre a helmintosporiose de Panicum maximum Jacq. cv. Tanzânia-1. Foi avaliado, em cinco períodos (dois, quatro, seis, oito e dez dias de incubação), o crescimento micelial do fungo sob cinco concentrações dos óleos essenciais $\left(\mathrm{C}_{1}=250 \mathrm{ppm} ; \mathrm{C}_{2}=500\right.$ $\left.\mathrm{ppm} ; \mathrm{C}_{3}=750 \mathrm{ppm} ; \mathrm{C}_{4}=1000 \mathrm{ppm} \mathrm{e} \mathrm{C}_{5}=1250 \mathrm{ppm}\right)$. Como controle alternativo, foi avaliado o efeito preventivo e curativo sobre a helmintosporiose de cinco tratamentos à base de óleo: capim-limão, citronela, erva-cidreira, hortelã-pimenta e nim em quatro concentrações $(2500 ; 5000 ; 7500$ e 10000 ppm). Os óleos essenciais de capim-limão e citronela foram os mais eficientes na redução do crescimento micelial do Helminthosporium sp. Sob o óleo essencial de erva-cidreira, o patógeno apresentou crescimento até na maior concentração (1250 ppm). Pelos resultados obtidos verificou-se que todos os óleos essenciais e concentrações avaliadas apresentaram efeito preventivo e curativo, reduzindo a severidade da helmintosporiose.

Palavras-chave: Plantas forrageiras. Óleos essenciais. Helminthosporium sp..

\footnotetext{
*Autor para correspondência

${ }^{1}$ Recebido para publicação em 07/05/2012; aprovado em 31/01/2013

Parte da Dissertação de Mestrado, da segunda autora, apresentada ao Programa de Pós-Graduação em Produção Vegetal da Universidade Federal do Tocantins/UFT

${ }^{2}$ Programa de Pós-Graduação em Produção Vegetal, Universidade Federal do Tocantins/UFT, Gurupi-TO, Brasil, gilrsan@ uft.edu.br ${ }^{3}$ Departamento de Ciências Agrárias e Tecnológicas, Universidade Federal do Tocantins/UFT, Gurupi-TO, Brasil, binhabio@uft.edu.br ${ }^{4}$ Programa de Pós-Graduação em Produção Vegetal, Universidade Federal do Tocantins/UFT, Gurupi-TO, Brasil, hguilhon@uft.edu.br, fidelisrr@uft.edu.br

${ }^{5}$ Universidade Federal de Viçosa/UFV, Rio Paranaíba-MG, Brasil, goncalvescg.agro@hotmail.com
} 


\section{INTRODUCTION}

Leaf spots are very common in important agricultural grasses, with forage grasses being worthy of note among the species of the Poaceae family. Species of the genus Panicum, are among those grasses most used as forage for cattle, principally the 'Vendor' and 'Tanzania' cultivars of Panicum maximum (BATISTOTI et al., 2011). Leaf spots caused by phytopathogenic fungi impair the rate of photosynthesis in the leaves, whichcanreducecropproduction(GODOY;AMORIM; BERGAMIN FILHO, 2001; MARTINEZ; FRANZENER; STANGARLIN, 2010) with considerable infections by the fungus Bipolaris maydis ( syn. Helminthosporium maydis) in the cv. 'Vendedor' and 'Tanzania' having been reported (MARTINEZ; FRANZENER; STANGARLIN, 2010).

Over recent years, attempts to prevent, control and eradicate plant disease have been centered on using synthetic chemicals. However, the continued and indiscriminate use of pesticides causes a host of environmental and humanhealth problems, such as the interruption of natural biological control (SOYLU; KURT; SOYLU, 2010), resistance by pathogens causing outbreaks of disease (LEE et al., 2008) and contamination of ground and surface water (FERNANDES NETO; SARCINELLI, 2009).

Many plants have a natural resistance to different pathogens, and this mechanism may be related to fungicidal compounds produced naturally by the plant (SALGADO et al., 2003). The identification of these chemical compounds from medicinal plants makes it possible to obtain substances which can control or inhibit the growth of phytopathogens (SILVA et al., 2009).

Originating from the secondary metabolism in plants, essential oils have a complex chemical composition, the presence of terpenes and phenylpropanoids being of note, and are considered sources of biologically active substances, mainly against microorganisms (OLIVEIRA et al., 2011; SIANI et al., 2000).

The essential oil of the peppermint (Mentha piperita L. (Lamiaceae)) has high antimicrobial potential against phytopathogens Aspergillus flavus and A. niger (HUSSAIN et al., 2010). The antimicrobial action of the oils from the neem (Azadirachta indica A. Juss. (Meliaceae)) and citronella (Cymbopogon nardus (L.) Rendle (Poaceae)) on soybean rust, caused by Phakopsora pachyrhizi, was observed by Medice et al. (2007). The essential oil of lemon grass (Cymbopogon citratus (DC.) Stapf (Poaceae)) inhibited the growth of the fungus Colletotrichum gloeosporioides (SILVA et al., 2009). The main constituents of the essential oil of $C$. citratus already identified, are geranial and neral, while citronellal, geraniol and citronellol are the major constituents of citronella (OLIVEIRA et al., 2011). Tagami et al. (2009) highlighted the antifungal potential of lemon balm (Lippia alba (Mill.) N.E. Br ex Britton \& P. Wilson (Verbenaceae)) on the mycelial growth of the fungus Colletotrichum graminicola.

Antifungal activity of essential oils is related to their hydrophobicity, which allows for interaction between the essential oil and lipids of the wall, cell membrane and mitochondria, this interaction altering permeability and causing disturbances in these structures (COSTA et al., 2011). Soylu, Kurt and Soylu (2010) observed morphological changes in the hyphae of Botrytis cinerea when treated with the essential oil of the oregano. This cytotoxic property of essential oils is very important in the application of these plant extracts in agriculture, since they can be effective in controlling phytopathogens (BAKKALI, 2008).

Considering the impact of leaf blotch disease on grasses destined for pasture, the growing demand for alternative methods of control, and the antifungal potential of the essential oils from medicinal plants, the objectives of this work were to evaluate the fungi-toxicity in vitro of the essential oils of lemongrass, citronella, lemon balm and peppermint on the phytopathogen Helminthosporium sp., and the in vivo effect of these oils and the commercial neem oil (NEEMAX ${ }^{\circledR}$ ) on leaf blotch in Tanzania grass.

\section{MATERIAL AND METHODS}

\section{Trial I: In vitro fungitoxicity of essential oils on Helminthosporium sp.}

The experiment was carried out at the Plant Pathology Laboratory of the Federal University of Tocantins, Gurupi Campus, in Tocantins.

The fungus Helminthosporium sp. was isolated from the leaves of Tanzania grass showing typical symptoms of leaf blotch. For the isolation, Petri dishes with $20 \mathrm{~mL}$ of a PDA (potato, dextrose and agar) culture medium were used.

To obtain the essential oils, leaves of lemongrass and citronella 172 days after transplanting, and flowering lemon balm leaves were collected. The leaves were dried at room temperature. Extraction was performed by hydro-distillation (CASTRO et al., 2010), using a Clevenger apparatus. The supernatants were collected and stored in sterile flasks sealed with foil. The peppermint oil (DOKMOS - Cosmetics ${ }^{\circledR}$ ) was purchased at the Gurupi Municipal Market.

For each essential oil, a completely randomized factorial design with four replications was used. The treatments consisted of five concentrations of oil $\left(\mathrm{C}_{1}=\right.$ $250 \mathrm{ppm}, \mathrm{C}_{2}=500 \mathrm{ppm}, \mathrm{C}_{3}=750 \mathrm{ppm}, \mathrm{C}_{4}=1,000 \mathrm{ppm}$ and $\mathrm{C} 5=1,250 \mathrm{ppm}$ ) and a control (dishes containing only the PDA culture medium), and five periods of evaluation (two, four, six, eight and ten days of incubation). 
To verify the effect of essential oils on the mycelial growth of phytopathogens, oils were spread over the surface of the culture medium at the above concentrations, with the aid of a Drigalsky handle. Then a disc of PDA, $6 \mathrm{~mm}$ in diameter, containing mycelia of the fungus was placed in the center of the dishes. The dishes were sealed with PVC plastic film, identified, and incubated in the dark at a temperature of $27 \pm 2{ }^{\circ} \mathrm{C}$.

Considering that the Helminthosporium sp. fungus presents slow growth, taking eight to 12 days to occupy the surface of a Petri dish of $90 \times 15 \mathrm{~mm}$, five evaluations were carried out (at two, four, six, eight and ten days of incubation) by measuring the mycelial diameter (the average of two diametrically opposite measurements), using digital calipers.

Trial II: In vivo fungitoxicity of essential oils on grass leaf blotch

The experiment was carried out at the Plant Pathology Laboratory and in greenhouses of the Federal University of Tocantins, Gurupi Campus, in Tocantins.

For the cultivation of the plants of $P$. maximun $\mathrm{cv}$. Tanzânia, $42 \times 27 \times 7 \mathrm{~cm}$ plastics trays were used, kept at a temperature of $27 \pm 5{ }^{\circ} \mathrm{C}$ in a greenhouse, with four litres of Germinar® commercial substrate and $10 \mathrm{~g}$ de NPK (5-25-15) fertiliser. Four rows were prepared per tray and 30 seeds were planted per row. The trays were watered twice daily with approximately $700 \mathrm{~mL}$ of water.

\section{The oils used were obtained as described in Trial I.}

For the preparation of the spore suspension, $15 \mathrm{ml}$ of distilled and sterile water were added to each dish containing an inoculum of the fungus. Detachment of the mycelium was carried out with the help of a soft-bristle brush. The suspension was filtered through gauze, and the spores were quantified in a Neubauer chamber.

To evaluate the preventive and curative effects on the grass leaf blotch, a completely randomized factorial design with four replications was used, in which the factors were five types of oil (citronella, lemongrass, lemon balm, peppermint and commercial neem - NEENMAX $®)$, and four oil concentrations $(2,500 ; 5,000 ; 7,500$ and 10,000 ppm). As a control, plants sprayed with water (absolute) and plants sprayed with methyl thiophanate at $1,000 \mathrm{ppm}$ (relative), a broad-spectrum fungicide, were used.

In order to evaluate the preventive effects, the plants were sprayed with $20 \mathrm{~mL}$ of the treatments using a hand spray 30 days after planting, and were inoculated after one hour with $20 \mathrm{~mL}$ of the spore suspension $\left(1.1 \times 105\right.$ spores $\left.\mathrm{mL}^{-1}\right)$. After inoculation with the pathogen, the plants were kept in a moist chamber in the dark for 48 hours in the laboratory. After the incubation period, the plants were placed in a natural environment at a temperature of $30 \pm 5{ }^{\circ} \mathrm{C}$, without any control over relative humidity or photoperiod, to enable the disease to develop. Severity assessment was performed nine days after inoculation, the period required for symptoms of blotch to have presented.

For the curative effect, the plants were inoculated with $20 \mathrm{~mL}$ of spore solution $\left(1.09 \times 105\right.$ spores $\left.\mathrm{mL}^{-1}\right)$, the evaluation of the severity of the leaf blot being made after four days. After this period, the plants were sprayed with $20 \mathrm{~mL}$ of the treatments and kept in a natural environment, being reevaluated after 15 days.

Disease severity was assessed using a rating scale: $0=$ healthy plant; $1=$ less than $1 \%$ diseased leaf area; $3=1-5 \%$ diseased leaf area; $5=6$ to $25 \%$ diseased leaf area; $7=26$ to $50 \%$ diseased leaf area; $9=$ more than $50 \%$ diseased leaf area (SANTOS et al., 2005).

\section{Statistical Design}

The data were subjected to variance (ANOVA) and regression analysis. For the qualitative factor, the means were compared by the Tukey test at $5 \%$ probability, and for the quantitative factor, regression equations were adjusted based on the t-test of the coefficients at $5 \%$ probability and of the coefficient of determination $\left(\mathrm{R}^{2}\right)$. The analyses were performed by the SAEG computer system (RIBEIRO JÚNIOR, MELO, 2008).

\section{RESULTS AND DISCUSSION}

\section{Trial I: In vitro fungitoxicity of essential oils on Helminthosporium sp.}

There was no mycelial growth of the Helminthosporium sp. fungus with the treatments with the lemongrass and citronella oils at concentrations of $\geq 750 \mathrm{ppm}\left(\mathrm{C}_{3}, \mathrm{C}_{4}\right.$ and $\left.\mathrm{C}_{5}\right)$, but under the action of the lemon balm and peppermint oils, the pathogen presented growth at all the doses evaluated (Table 1). After 10 days of incubation, only the concentrations $\geq \mathrm{C}_{2}$ (500 ppm) and $\geq \mathrm{C}_{3}$ (750 ppm) of the lemon balm and peppermint oils respectively, had significantly reduced the mycelial diameter of the Helminthosporium sp. Variance analysis showed that the concentrations, evaluation periods and interaction between these factors was significant at $1 \%$ for the estimates of mycelial growth of the Helminthosporium sp. fungus under the treatments being represented by the regression equations (Table 1).

Concentration $\mathrm{C}_{2}(500 \mathrm{ppm})$ of lemongrass oil reduced the daily mycelial growth of Helminthosporium sp. from $7.22 \mathrm{~mm} \mathrm{day}^{-1}$ (control) to $1.63 \mathrm{~mm} \mathrm{day}^{-1}$. The main component of the essential oil of lemongrass is citral, and antifungal activity is a prominent property 
Table 1 - Mycelial growth (mm) of Helminthosporium sp. subjected to different concentrations of the essential oils of lemongrass, citronella, lemon balm and peppermint, for five evaluation periods $(2 ; 4 ; 6 ; 8$ and 10 days of incubation)

\begin{tabular}{|c|c|c|c|c|c|c|c|}
\hline \multirow{3}{*}{ Concentration } & \multicolumn{5}{|c|}{ Evaluation period (days of incubation) } & \multirow{2}{*}{ Regression } & \multirow{2}{*}{$\mathrm{R}^{2}$} \\
\hline & 2 & 4 & 6 & 8 & 10 & & \\
\hline & \multicolumn{7}{|c|}{ Lemongrass } \\
\hline Test & $24.5 \mathrm{a}$ & $58.6 \mathrm{a}$ & $80.9 \mathrm{a}$ & $84.0 \mathrm{a}$ & $84.0 \mathrm{a}$ & $\hat{\mathrm{y}}=23.04+7.22 \mathrm{EA}^{* *}$ & 0.79 \\
\hline $\mathrm{C} 1$ & $0.0 \mathrm{~b}$ & $2.6 \mathrm{~b}$ & $19.0 \mathrm{~b}$ & $38.9 \mathrm{~b}$ & $62.9 \mathrm{~b}$ & $\hat{y}=-23.04+8.11 \mathrm{EA}^{* *}$ & 0.93 \\
\hline \multirow[t]{2}{*}{$\mathrm{C} 2$} & $0.0 \mathrm{~b}$ & $0.0 \mathrm{~b}$ & $0.0 \mathrm{c}$ & $0.0 \mathrm{c}$ & $16.3 \mathrm{c}$ & $\hat{y}=-6.52+1.63 E^{* * *}$ & 0.49 \\
\hline & \multicolumn{7}{|c|}{ Citronella } \\
\hline Test & $24.5 \mathrm{a}$ & $58.6 \mathrm{a}$ & $80.9 \mathrm{a}$ & $84.0 \mathrm{a}$ & $84.0 \mathrm{a}$ & $\hat{y}=23.04+7.22 \mathrm{EA}^{* *}$ & 0.79 \\
\hline $\mathrm{C} 1$ & $0.0 \mathrm{~b}$ & $11.5 \mathrm{~b}$ & $25.7 \mathrm{~b}$ & $42.2 \mathrm{~b}$ & $55.5 \mathrm{~b}$ & $\hat{y}=-15.52+7.08 E^{* *}$ & 0.96 \\
\hline \multirow[t]{2}{*}{$\mathrm{C} 2$} & $0.0 \mathrm{~b}$ & $0.7 \mathrm{c}$ & $8.5 \mathrm{c}$ & $19.4 \mathrm{c}$ & $31.8 \mathrm{c}$ & $\hat{y}=-12.59+4.11 \mathrm{EA}^{* *}$ & 0.79 \\
\hline & \multicolumn{7}{|c|}{ Lemon balm } \\
\hline Test & $24.5 \mathrm{a}$ & $58.6 \mathrm{a}$ & $80.9 \mathrm{a}$ & $84.0 \mathrm{a}$ & $84.0 \mathrm{a}$ & $\hat{y}=23.04+7.22 \mathrm{EA}^{* *}$ & 0.79 \\
\hline $\mathrm{C} 1$ & $5.5 \mathrm{~b}$ & $23.5 \mathrm{~b}$ & $44.6 \mathrm{~b}$ & $65.3 \mathrm{~b}$ & $79.1 \mathrm{a}$ & $\hat{y}=-13.12+9.45 \mathrm{EA}^{* *}$ & 0.94 \\
\hline $\mathrm{C} 2$ & $0.0 \mathrm{~b}$ & $3.1 \mathrm{c}$ & $14.0 \mathrm{c}$ & $28.0 \mathrm{c}$ & $45.0 \mathrm{~b}$ & $\hat{y}=-16.46+5.75 \mathrm{EA}^{* *}$ & 0.88 \\
\hline $\mathrm{C} 3$ & $0.0 \mathrm{~b}$ & $0.0 \mathrm{c}$ & $3.2 \mathrm{~d}$ & $12.3 \mathrm{~d}$ & $23.1 \mathrm{c}$ & $\hat{y}=-9.84+2.93 E^{* *}$ & 0.80 \\
\hline $\mathrm{C} 4$ & $0.0 \mathrm{~b}$ & $0.0 \mathrm{c}$ & $0.0 \mathrm{~d}$ & $4.8 \mathrm{de}$ & $13.6 \mathrm{~d}$ & $\hat{y}=-5.93+1.60 \mathrm{EA}^{* *}$ & 0.70 \\
\hline \multirow[t]{2}{*}{$\mathrm{C} 5$} & $0.0 \mathrm{~b}$ & $0.0 \mathrm{c}$ & $0.0 \mathrm{~d}$ & $1.4 \mathrm{e}$ & $6.0 \mathrm{~d}$ & $\hat{y}=-2.56+0.67$ EA** & 0.49 \\
\hline & \multicolumn{7}{|c|}{ Peppermint } \\
\hline Test & $24.5 \mathrm{a}$ & $58.6 \mathrm{a}$ & $80.9 \mathrm{a}$ & $84.0 \mathrm{a}$ & $84.0 \mathrm{a}$ & $\hat{\mathrm{y}}=23.04+7.22 \mathrm{EA}^{* *}$ & 0.79 \\
\hline $\mathrm{C} 1$ & $5.8 \mathrm{~b}$ & $24.3 \mathrm{~b}$ & $47.7 \mathrm{~b}$ & $70.2 \mathrm{~b}$ & $79.2 \mathrm{a}$ & $\hat{y}=-12.18+9.59 \mathrm{EA}^{* *}$ & 0.91 \\
\hline $\mathrm{C} 2$ & $0.0 \mathrm{~b}$ & $12.2 \mathrm{c}$ & $33.4 \mathrm{c}$ & $60.4 \mathrm{~b}$ & $78.8 \mathrm{a}$ & $\hat{y}=-24.96+10.33 E^{*} * *$ & 0.95 \\
\hline $\mathrm{C} 3$ & $0.0 \mathrm{~b}$ & $1.1 \mathrm{~d}$ & $7.0 \mathrm{~d}$ & $22.8 \mathrm{c}$ & $48.6 \mathrm{~b}$ & $\hat{\mathrm{y}}=-19.73+5.94 \mathrm{EA}^{* *}$ & 0.83 \\
\hline $\mathrm{C} 4$ & $0.0 \mathrm{~b}$ & $0.0 \mathrm{~d}$ & $0.3 \mathrm{~d}$ & $6.8 \mathrm{~d}$ & $17.9 \mathrm{c}$ & $\hat{y}=-7.76+2.13 E^{* *}$ & 0.73 \\
\hline $\mathrm{C} 5$ & $0.0 \mathrm{~b}$ & $0.0 \mathrm{~d}$ & $0.0 \mathrm{~d}$ & $1.7 \mathrm{~d}$ & $9.8 \mathrm{c}$ & $\hat{\mathrm{y}}=-4.11+1.07 \mathrm{EA}^{* *}$ & 0.62 \\
\hline
\end{tabular}

Averages followed by the same letter in a column for each type of oil, do not differ by the Tukey test at $5 \%$ significance; ** Significant at $1 \%$ probability by t-test

of this oil (SILVA et al., 2009). Oliveira et al. (2011) relate the antimicrobial potential of lemongrass oil to its major components, the monoterpene aldehydes, neral and geranial.

The essential oil of citronella reduced the rate of growth of Helminthosporium sp. and slowed its development. Under the concentrations $C_{1}(250 \mathrm{ppm})$ and $\mathrm{C}_{2}(500 \mathrm{ppm})$ the fungus presented a growth rate of $7.08 \mathrm{~mm}$ and $4.11 \mathrm{day}^{-1}$ respectively. Development of the pathogen was only observed under these concentrations at the second evaluation after four days of incubation (Table 1). Medice et al. (2007), using the essential oil of citronella, observed inhibition of spore germination of the fungus Phakopsora pachyrhizi, the causal agent of Asian soybean rust. Oliveira et al. (2011), evaluating the chemical composition of the essential oil of citronella, highlighted as major compounds the aldehyde citronellal and the alcohols geraniol and citronellol, all compounds responsible for the antimicrobial activity of the oil.

The lowest rate of daily mycelial growth, observed when the Helminthosporium sp. was subjected to the lemongrass oil, was $0.67 \mathrm{~mm} \mathrm{day}^{-1}$ at concentration $\mathrm{C}_{5}(1,250 \mathrm{ppm}$ ) (Table 1$)$. After 10 days of incubation, this growth rate gave the fungus a $4.14 \mathrm{~mm}$ mycelial diameter, a size $95.6 \%$ smaller than that obtained at the same evaluation by the control, where the mycelial diameter was $94.24 \mathrm{~mm}$. When subjected to the essential oil of peppermint, estimates of the growth rates of the Helminthosporium sp. under the concentrations $\mathrm{C}_{1}$ and $\mathrm{C}_{2}$, were 9.59 and $10.33 \mathrm{~mm}^{\text {days }}{ }^{-1}$ respectively. Despite being greater than the growth rate obtained by the control $\left(7.22 \mathrm{~mm} \mathrm{day}^{-1}\right)$, the mycelial diameters of 
the fungus at the last evaluation were smaller. This is because there was a delay in the development of the pathogen. Under $\mathrm{C}_{2}$, growth of the Helminthosporium sp. was observed after four days of incubation (Table 1). The antifungal activity of the peppermint oil is probably due to the presence of menthol and carvone, both antifungal compounds (FREIRE, 2006).

There are studies that describe the direct activity of essential oils from plants on phytopathogens, or indirectly by activating the defense mechanisms of the plants against pathogens (FRANZENER et al., 2003; SALGADO et al., 2003; ZACARONI et al., 2009; ZANANDREA et al., 2004).

\section{Trial II: In vivo fungitoxicity of essential oils on grass leaf blotch}

For the preventive effect on Tanzania grass leaf blotch, those plants treated with the fungicide methyl thiophanate showed no symptoms of the disease.

The results for the preventive effect of essential oils on Tanzania grass leaf blotch (Table 2) showed that all the oils evaluated reduced the severity of disease.

Under the concentration of 2,500 ppm of commercial Neem oil, the plants showed a significantly lower severity rating than those treated with the essential oils of lemongrass and lemon balm (Table 2). The preventive action of the Neem oil was efficient in controlling angular blight in the bean, whose causal agent is Phaeoisariopsis griseola, (CARNEIRO; PIGNONI; GOMES, 2008), however in other studies (MARTINEZ, 2002; PIGNONI; CARNEIRO, 2005), it was found that neem showed low efficiency in the control of disease, due to the environmental conditions, the inoculum pressure being extremely favourable to the development of symptoms of disease, the decomposition of azadirachtin over time, and the small effect of the active compounds from neem on the fungi tested.
The essential oil of peppermint, at a concentration of $5000 \mathrm{ppm}$ was effective in reducing the severity of leaf blotch in the grass, an increase in concentration not reducing the grade of severity (Table 2). The in vivo antimicrobial activity of the essential oil of peppermint was observed by Fatemi et al. (2011), where the essential oil was effective in reducing the decomposition of oranges (Citrus sinensis) caused by species of Penicillium.

There was no significant difference between the average ratings of disease severity when plants were exposed to concentrations of 7,500 and 10,000 ppm of the essential oils tested (Table 2).

For the curative effect, before application of the treatments, the plants presented between 1 and 5\% diseased leaf area, thereby receiving a rating of three for the severity of the leaf spot.

As there was no interaction between the essential oils and treatments used, the effects were studied separately (Table 3). The results observed showed that there was no significant difference between the evaluated essential oils in the healing of leaf blotch.

When comparing concentrations it can be seen that the essential oils of citronella, lemongrass, lemon balm, peppermint and neem oil, at concentrations of 2,500; 5,$000 ; 7,500$ and $10,000 \mathrm{ppm}$, and of the fungicide methyl thiophanate, significantly reduced the severity ratings of the grass leaf blotch, since only in the absolute control did the disease progress to rating 7 (Table 3).

Perini et al. (2011) verifying the curative effect of citronella oil on rice blast, caused by Pyricularia grisea, found a reduction of up to $50 \%$ in the number of plants with symptoms of the disease. The curative effect of neem oil was verified by Carneiro (2003). The author observed controlling of powdery mildew in the tomato, Oidium lycopersici, using concentrations of 0.25 to $2 \%$ of neem

Table 2 - Severity of leaf blotch under the preventive effect of essential oils applied in four dosages in Tanzania grass plants inoculated with the Helminthosporium sp. fungus

\begin{tabular}{lcccccccc}
\hline \multirow{2}{*}{ Essential oil } & \multicolumn{9}{c}{ Concentrations $(\mathrm{ppm})$} & & \multirow{2}{*}{ Regressão equation } & $\mathrm{R}^{2}$ \\
\cline { 2 - 5 } & 0 & 2500 & 5000 & 7500 & 10000 & & 0.70 \\
Lemongrass & $7 \mathrm{a}$ & $4.5 \mathrm{a}$ & $3.5 \mathrm{ab}$ & $3 \mathrm{a}$ & $3 \mathrm{a}$ & & $\hat{\mathrm{y}}=6.10-0.019 \mathrm{C}^{* *}$ & 0.49 \\
Citronella & $7 \mathrm{a}$ & $3.5 \mathrm{ab}$ & $3.5 \mathrm{ab}$ & $3.5 \mathrm{a}$ & $3 \mathrm{a}$ & $\hat{\mathrm{y}}=5.70-0.016 \mathrm{C}^{* *}$ & 0.49 \\
Lemon balm & $7 \mathrm{a}$ & $4.5 \mathrm{a}$ & $4.5 \mathrm{a}$ & $3.5 \mathrm{a}$ & $3 \mathrm{a}$ & $\hat{\mathrm{y}}=6.30-0.018 \mathrm{C}^{* *}$ & 0.69 \\
Peppermint & $7 \mathrm{a}$ & $3.5 \mathrm{ab}$ & $3 \mathrm{~b}$ & $3 \mathrm{a}$ & $3 \mathrm{a}$ & $\hat{\mathrm{y}}=5.60-0.017 \mathrm{C}^{* *}$ & 0.56 \\
Neem & $7 \mathrm{a}$ & $3 \mathrm{~b}$ & $3.5 \mathrm{ab}$ & $3 \mathrm{a}$ & $3.5 \mathrm{a}$ & & $\hat{\mathrm{y}}=\overline{\mathrm{x}}=4$ & - \\
\hline
\end{tabular}

Averages followed by the same letter in any one column do not differ by the Tukey test (P>0.05). ** Significant at 1 by the t-test; Ratings for severity: $0=$ healthy plant; $1=$ less than $1 \%$ diseased leaf area; $3=1-5 \%$ diseased leaf area; $5=6$ to $25 \%$ diseased leaf area; $7=26$ to $50 \%$ diseased leaf area; $9=$ more than $50 \%$ diseased leaf area 
Table 3 - Severity of leaf blotch under the curative effect of essential oils applied in four dosages in Tanzania grass plants inoculated with the Helminthosporium sp. fungus

\begin{tabular}{lcccccccc}
\hline \multirow{2}{*}{ Essential oil } & \multicolumn{5}{c}{ Concentration - OE $(\mathrm{ppm})$} & \multirow{2}{*}{ T1 } & \multirow{2}{*}{ T2 } & \multirow{2}{*}{ Comparisons } \\
\cline { 2 - 5 } & 2500 & 5000 & 7500 & 10000 & & 7 & 3.5 & $3.75 \mathrm{a}$ \\
Lemongrass & 3 & 3 & 3 & 3 & 7 & 3.5 & $3.92 \mathrm{a}$ \\
Citronella & 3.5 & 3.5 & 3 & 3 & 7 & 3.5 & $4.08 \mathrm{a}$ \\
Lemon balm & 3.5 & 3.5 & 3.5 & 3.5 & 7 & 3.5 & $3.92 \mathrm{a}$ \\
Peppermint & 3.5 & 3.5 & 3 & 3 & 7 & 3.5 & $3.83 \mathrm{a}$ \\
Neem & 3 & 3.5 & 3 & 3 & $7 \mathrm{~A}$ & $3.5 \mathrm{~B}$ & \\
\hline Comparisons & $3.3 \mathrm{~B}$ & $3.4 \mathrm{~B}$ & $3.1 \mathrm{~B}$ & $3.1 \mathrm{~B}$ & & 7.5 \\
\hline
\end{tabular}

Averages followed by the same letter, lowercase in a column and uppercase on a line, do not differ by the Tukey test (P>0.05); T1 - water, T2 - Methyl tiophanate at 1000 ppm.; Ratings for severity: $0=$ healthy plant; $1=$ less than $1 \%$ diseased leaf area; $3=1-5 \%$ diseased leaf area; $5=6$ to $25 \%$ diseased leaf area; $7=26$ to $50 \%$ diseased leaf area; $9=$ more than $50 \%$ diseased leaf area

oil. The antimicrobial effect of the neem may be related to the compound azadirachtin, considered to be the main active component of the plant (ALVES et al., 2009).

The in vivo action of plant extracts on another species of Helmintosporium was observed by Franzener et al. (2003). The authors examined the action of the aqueous extract of camphor on wheat brown spot, caused by the fungus Bipolaris sorokiniana (syn. Helminthosporium sorokiniana), and observed a significant reduction in the number and size of the lesions.

Essential oils inhibit or reduce the growth of phytopathogens due to the action of substances in their composition. These substances may affect the integrity of cell membranes, causing spillage of cellular contents (PEREIRA et al., 2011). Costa et al. (2011), evaluating the effect of the essential oil of the clove (Syzygium aromaticum) on the hyphae of $R$. solani, observed different morphological changes, such as the presence of vacuoles, disruption of cellular contents, decrease in the sharpness of the cell wall, intense fragmentation and less turgescence of the hyphae.

The use of essential oils as antimicrobial agents is considered low risk, since it is believed that it is difficult for a pathogen to develop resistance to the complex mixture of active components that make up these oils (DERBALAH; DEWIR, EL-SAYED, 2012). According to Al-Reza et al. (2010), essential oils are antifungal agents with promising potential for agro-industry, since their active compounds may exhibit different forms of invasion in order to inhibit the growth of phytopathogens.

\section{CONCLUSIONS}

1. The essential oils of lemongrass and citronella showed potential in the control of Heminthosporium sp., significantly reducing the mycelial growth of the pathogen;
2. The essential oils of lemongrass, citronella, lemon balm, peppermint and neem may be an alternative to synthetic fungicides and a prominent tool for integrated disease management, since they significantly reduced leaf blotch in Tanzania grass.

\section{REFERENCES}

AL-REZA, S. M. et al. Inhibition of plant pathogens in vitro and in vivo with essential oil and organic extracts of Cestrum nocturnum L. Pesticide Biochemistry and Physiology, v. 96, n. 2, p. 86-92, 2010.

ALVES, P. D. etal. Chromatographic evaluation and antimicrobial activity of Neem (Azadirachta indica A. Juss., Meliaceae) leaves hydroalcoholic extracts. Revista Brasileira de Farmacognosia, v. 19 , n. 2 B, p. $510-515,2009$.

ANJOS, J. R. N. et al. Ocorrência de Bipolaris maydis causando mancha foliar em Paspalum atratum cv. Pojuca no Brasil. Fitopatologia Brasileira, v. 29, n. 6, p. 656-658, 2004.

BAKKALI, F. et al. Biological effects of essential oils - A review. Food and Chemical Toxicology, v. 46, n. 2, p. 446-475, 2008.

BATISTOTI, C. et al. Correlations among anatomical, morphological, chemical and agronomic characteristics of leaf blades in Panicum maximum genotypes. Animal Feed Science and Technology, v. 171, n. 2/4, p. 173-180, 2011.

CARNEIRO, S. M. T. P. G. Efeito de extratos de folhas e do óleo de nim sobre o oídio do tomateiro. Summa Phytopathologica, v. 29, n. 3, p. 262-265, 2003.

CARNEIRO, S. M. T. P. G.; PIGNONI, E.; GOMES, J. C. Efeito do nim (Azadirachta indica A. Juss.) no controle da mancha angular do feijoeiro. Revista Brasileira de Plantas Medicinais, v. 10, n. 3, p. 6-10, 2008.

CASTRO, H. G. et al.Avaliação do teore composição doóleo essencial de Cymbopogon nardus (L.) em diferentes épocas de colheita. Revista Ciência Agronômica, v. 41, n. 2, p. 308-314, 2010. 
COSTA, A. R. T. et al. Ação do óleo essencial de Syzygium aromaticum (L.) Merr. \& L.M. Perry sobre as hifas de alguns fungos fitopatogênicos. Revista Brasileira de Plantas Medicinais, v. 13, n. 2, p. 240-245, 2011.

DERBALAH, A. S.; DEWIR, Y. H.; EL-SAYED, A. E. Antifungal activity of some plant extracts against sugar beet damping-off caused by Sclerotium rolfsii. Annals of Microbiology, v. 62, n. 3, p. 1021-1029, 2012.

FATEMI, S. et al. Effect of essential oils of Thymus vulgaris and Mentha piperita on the control of green mould and postharvest quality of Citrus Sinensis cv. Valencia. African Journal of Biotechnology, v. 10, n. 66, p. 14932-14936, 2011.

FERNANDES NETO, M.; SARCINELLI, P. N. Agrotóxicos em água para consumo humano: uma abordagem de avaliação de risco e contribuição ao processo de atualização da legislação brasileira. Revista Engenharia Sanitária e Ambiental, v. 14, n. 1, p. 69-78, 2009.

FRANZENER, G. et al.. Atividade antifúngica e indução de resistência em trigo a Bipolaris sorokiniana por Artemisia camphorata. Acta Scientiarum. Agronomy, v. 25, n. 2, p. 503-507, 2003.

FREIRE, M. M. Composição e atividade antifúngica do óleo essencial de hortelã-pimenta (Mentha piperita L.). $2006.67 \mathrm{f}$. Dissertação (Mestrado em Agroquímica) - Universidade Federal de Viçosa, Viçosa, 2006.

GODOY, C. V.; AMORIM, L.; BERGAMIN FILHO, A. Alterações na fotossíntese e na transpiração de folhas de milho infectadas por Phaeosphaeria maydis. Fitopatologia Brasileira, v. 26, n. 2, p. 209-213, 2001.

HUSSAIN, A. et al. Seasonal variation in content, chemical composition and antimicrobial and cytotoxic activities of essential oils from four Mentha species. Journal of the Science of Food and Agriculture, v. 90, n. 11, p. 1827-1836, 2010.

LEE, Y. et al. Antifungal activity of Myrtaceae essential oils and their components against three phytopathogenic fungi. Flavour Fragrance Journal, v. 23, n. 1, p. 23-28, 2008.

MARTINEZ, A. S.; FRANZENER, G.; STANGARLIN, J. R. Dano causado por Bipolaris maydis em Panicum maximum cv. Tanzânia. Semina: Ciências Agrárias, v. 31, n. 4, p. 863-870, 2010.

MARTINEZ, A. S. O Nim. Azadirachta indica - natureza, usos múltiplos, produção. Londrina: IAPAR, 2002. 142 p.

MEDICE, R. et al. Óleos essenciais no controle da ferrugem asiática da soja Phakopsora pachyrhizi syd. \& p. Syd. Ciência e Agrotecnologia, v. 31, n. 1, p. 83-90, 2007.

OLIVEIRA, M. M. M. et al. Rendimento, composição química e atividade antilisterial de óleos essenciais de espécies de
Cymbopogon. Revista Brasileira de Plantas Medicinais, v. 13, n. 1, p. $8-16,2011$.

PEREIRA, R. B. et al. Potential of essential oils for the control of brown eye spot in coffee plants. Ciência e Agrotecnologia, v. 35, n. 1, p. 115-123, 2011.

PERINI, V. B. M. et al. Avaliação do efeito curativo e preventivo do óleo essencial do capim citronela no controle de Pyricularia grisea. Journal of Biotechnology and Biodiversity, v. 2, n. 2, p. 23-27, 2011.

PIGNONI, E.; CARNEIRO, S. M. T. P. G. Severidade da antracnose em feijoeiro e pinta preta em tomateiro sob diferentes concentrações de óleo de nim em casa de vegetação. Revista Brasileira de Plantas Medicinais, v. 8, n. 1, p. 68-72, 2005.

RIBEIRO JÚNIOR, J. I.; MELO, A. L. P. Guia Prático para Utilização do SAEG. Viçosa: UFV, 2008. 288 p.

SALGADO, A. P. S. P. et al. Avaliação da atividade fungitóxica de óleos essenciais de folhas de Eucalyptus sobre Fusarium oxysporum, Botrytis cinerea e Bipolaris sorokiniana. Ciência e Agrotecnologia, v. 27, n. 2, p. 249-254, 2003.

SANTOS, G. R. et al. Progresso do crestamento gomoso e perdas na cultura da melancia. Horticultura Brasileira, v. 23, n. 2, p. 228-232, 2005.

SIANI, A. C. et al. Óleos essenciais: Potencial antiinflamatório. Biotecnologia, Ciência e Desenvolvimento, v. 3 , n. 16 , p. $38-43,2000$

SILVA, A. C. et al. Efeito in vitro de compostos de plantas sobre o fungo Colletotrichum gloeosporioides Penz. isolado do maracujazeiro. Ciência e Agrotecnologia, v. 33, p. 1853 -1860, 2009. Número especial.

SOYLU, E. M.; KURT, S.; SOYLU, S. In vitro and in vivo antifungal activities of the essential oils of various plants against tomato grey mould disease agent Botrytis cinerea. International Journal of Food Microbiology, v. 143, n. 3, p. 183-189, 2010.

TAGAMI, O. K. et al. Fungitoxidade de Bidens pilosa, Thymus vulgaris, Lippia alba e Rosmarinus officinalis no desenvolvimento in vitro de fungos fitopatogênicos. Semina: Ciências Agrárias, v. 30, n. 2, p. 285-294, 2009.

ZACARONI, L. M. et al. Potencial fungitóxico do óleo essencial de Piper hispidinervum (pimenta longa) sobre os fungos fitopatogênicos Bipolaris sorokiniana, Fusarium oxysporum e Colletotrichum gloeosporioides. Acta Amazônica, v. 39, n. 1, p. 193-198, 2009.

ZANANDREA, L. et al. Atividade do óleo essencial de orégano contra fungos patogênicos do arroz: crescimentos micelial em placas. Revista Brasileira de Farmacognosia, v. 14, p. 14-16, 2004. Suplemento 1. 